\title{
The Influence of Leadership and Organizational Structure on The Quality of Accounting Information System
}

\author{
Rapina* \\ Department of Accounting, Maranatha Christian University, Sumantri No.65, 40164, Bandung, Indonesia
}

\begin{abstract}
Objective - The purpose of this research is to test and find empirical evidences on the effect of leadership and organization structure in the quality of accounting information system.

Methodology/Technique - The analytical units used in this research are state-owned enterprises enlisted in Bandung. The total samples are 49 respondents worked for state-owned enterprises in Bandung. Sample selection is done using purposive sampling method. The hypothesis in this study is tested by using multiple linear regression.

Findings - There are two variables that significantly influence quality of accounting information system. These are leadership and organizational structure.

Novelty - The study looked at the effect of leadership and organizational structure that significantly influence quality of accounting information system.
\end{abstract}

Type of Paper: Empirical.

Keywords: Leadership; Organizational Structure; AIS; Information System; System.

JEL Classification: M15, M41.

\section{Introduction}

More and more organizations are realizing that quality information is essential to the success of business activities (Guo, 2008). Quality accounting information is one of the competitive advantages for an organization (Xu, 2009). Quality accounting information is produced by quality accounting information system as well (Hall, 2011). According to Bodnar and Hopwood (2014), accounting information system consists of a collection of resources such as people and equipment which are designed to change the financial and other data into accounting information with the goal of satisfying the information needs of various users. Whereas Mitchel et al. (2000) stated that accounting information system should be able to be used as a tool in short term management control, and to generate information for the internal users such as the final price, cost and cash flow. Accounting information system will generate accounting information which will be used in the decisionmaking process by users as an internal management and also external users (Hall, 2011). According to Beest et al. (2009), investment and credit decisions made by capital providers and other stakeholders will be affected by a good accounting information quality. In line with that, Baltzan (2012) stated that a good accounting

\footnotetext{
* Paper Info: Received: February 28, 2017

Accepted: July 14, 2017

* Corresponding author:

E-mail: rapinacen@yahoo.com

Affiliation: Department of Accounting, Maranatha Christian University, Indonesia
} 
information quality is used to assist information users in making beneficial decisions. Therefore, accounting information system developed by the organization should be able to provide information which refers to accounting activity monitoring and adopting rules or accounting standards (Lupasc et al, 2009). There is no quality accounting information without quality accounting information system for quality accounting information system is an integration of quality hardware, software, brain ware, telecommunication network and database as well as quality of work and satisfaction of users (Sacer et al., 2006).

An important point stated by Laudon and Laudon (2007) is that an information system has to be built with clear understanding by the organization in which the information system will be used. Organizational factors which need to be considered in creating a new system and be the researcher's focus are leadership concept (Laudon and Laudon, 2007) and organizational structure (Wilkinson et al, 2000). A leader is a person who inspires others to be the best and knows the right way to manage time and speed for the whole group (Sciarra and Dorsey, 2012). Leadership is not what we do, but what others do as a response to our competency (Greenberg, 2011). Likewise, an organization structure will affect the success of an information system project (Wilkinson et al, 2000). There has to be a harmony between a company's structure and infrastructure with its information system's structure and infrastructure (Tricker, 1993). A compatibility of a company's infrastructure with its information system's infrastructure is an important post in the quality of the information system project (Laudon and Laudon, 2007). Therefore, in relation with the backgrounds mentioned above, there's a need for a research to be able to give empirical evidence about the influence and relation between leadership and organization structure on the quality of accounting information system.

\section{Literature Review}

\subsection{Leadership Influence on Accounting Information System}

Cho et al (2011) finds a positive impact of leadership to the information system success rate through two psychological mechanisms for the system users, namely perceived organizational support and systems, selfefficacy by using samples of 251 employees of a multinational bank in Korea. The abilities of group leadership are challenged mainly in terms of environment, people and technical system quality for information system implementation (Jacobs, 2012). The key factors derive from this implementation contributes to the understanding of the importance of managing leadership qualities of all team members in order to achieve the goal. Failure in information system implementation is not in accordance with hardware and software aspects of the new system, but more related to a leader's skills in noticing changes that happen in the organization (Kavanagh et al, 2012). Soja's (2009) research outcome emphasize the importance of leadership in the ERP success rate, where leadership is also seen as an organizational key in top management level, project management level and the function of information system, in order to have a successful implementation of the ERP. Bodie (2006) in his empirical findings stated that leadership and integration of information technology management framework as a reputable approach that needs to be considered to achieve performance effectiveness of said organization. That framework describes the relationship of transformational leadership on the corporate governance of technology information management, enterprise architecture, portfolio management and capital planning and investment control activity. This view is also shared by Goldkuhl and Rostlinger (2006), only in the hands of a competent leader, information system can generate information needed to determine rational decisions and enable control and precise coordination of every aspect within an organization. Bass and Riggio (2006) stated that when an organization needed to change in order to reflect the changes in technology, the environment and leadership in accomplishing the program become very important in the merging of information and technological change. Laudon and Laudon (2007) said that in order to gain maximum benefits, information system should be built with a clear understanding by an organization in which the system is going to be used. Based on his experience, one of the crucial factors needed to be taken into consideration when planning a system is the leadership and type of organization. Based on conceptual theories in this research which had been mentioned previously and some research outcome supporting those theories, it 
can be concluded that leadership influenced accounting information system with the following hypotheses was introduced:

H1: Leadership influence the Accounting Information System Quality

\subsection{Organization Structure Influence on Accounting Information System}

According to Wilkinson et al (2000), organization structure has significant impact on information system and information system's components, namely accounting information system. Some critical correlations that would appear should be understood by the system developer. Organization structure determines flows as the key in the accounting information system quality. This vertical flow conveys the information needed by the manager in doing their responsibilities. Organization structure influence accounting information system because organization structure is a tool for the manager in governing policies, control, budget allocation and information service planning within an organization (Bodnar and Hopwood, 2014). According to Romney and Steinbart (2012), organization structure affects accounting information system because AIS design, production needs to understand the organization structure in order to have the most relevant financial information for planning and control purposes. Information and organizational system influence one another, information system used by manager to serve the interest of an organization (McLeod and Schell, 2001). The relationship of information system and organization is a complex thing and is affected by many factors, one of them is an organization structure (McLeod and Schell, 2001). In line with that, Stair and Reynolds (2010) stated that the organizational structure depends on the objectives and management approach and may influence the use of information systems. Mukherji (2002), in his empirical findings stated that information system and organization structure have a strong connection with one another. The main challenge for business managers and practitioners is to develop information system solutions which able to overcome business problems. Internal organization structure is also affecting the success rate of information system projects. There has to be a harmony between a company's structure and infrastructure with an information system's structure and infrastructure (Modrak, 2007). Based on the conceptual theories in this research which had been mentioned above and some latest research supporting those theories, a conclusion can be drawn that organization structure influence accounting information system with the following hypotheses was introduced:

H2: Organization structure influence the Accounting Information System Quality

\section{Research Methodology}

The method used in this research is descriptive analysis method by using survey approach. The objects of this research are Leadership, Organization Structure and Accounting Information System Quality. This research is done on state-owned enterprises in the city of Bandung. The observational unit is accounting department which performs recording activities to making financial statement. Type of data used in this survey is primary data. These data are maintained from original sources, gathered through survey by sending direct questionnaires to accounting personnel working at state-owned enterprises in Bandung. One hundred and fifty copies of questionnaires were successfully spread on three state-owned enterprises in Bandung. Out of those 150 copies spread, 49 copies were returned by coming to the analytical unit. Three state-owned enterprises participated in this research are The Indonesian Railways Company (Ltd.), The Indonesian Postal Company (Ltd.) and Biofarma (Co, Ltd.). Data gathered are processed using SPSS.

\section{Results}

Based on validity test result, it can be said that all items are valid for X1, X2 and Y variables because the scores are $r>0.3$. In this research, the author used reliability test using Cornbach's Alpha. Criteria used is Cornbach's Alpha $>0.60$ is said to be reliable. Based on reliability test result, it can be said that all items are reliable for $\mathrm{X} 1, \mathrm{X} 2$ and $\mathrm{Y}$. 
These are the results of multiple regression equation:

Table 1 Multiple Linear Regression

\begin{tabular}{|l|l|l|l|l|l|}
\hline \multicolumn{6}{|c|}{ Coefficients $^{\mathbf{a}}$} \\
\hline Model & Unstandardized Coefficients & $\begin{array}{l}\text { Standardized } \\
\text { Coefficients }\end{array}$ & t & Sig. \\
\hline & B & Std. Error & Beta & & \\
\hline (Constant) & 13.278 & 5.335 & & 2.489 & .017 \\
\hline TOTALK & .947 & .348 & .387 & 2.724 & .009 \\
\hline TOTALSO & .541 & .247 & .311 & 2.188 & .034 \\
\hline
\end{tabular}

a. Dependent Variable: TOTALSIA

b. Based on table 1, this linear regression equation is obtained:

$\mathrm{Y}=13.278+0.947 \mathrm{X} 1+0.541 \mathrm{X} 2+\mathrm{e}$

\section{Discussion}

\subsection{Hypotheses Test Result of Leadership Influence on Accounting Information System Quality (H1)}

The researcher will test hypotheses 1, which says "Leadership influence on Accounting Information System Quality". Multiple Linear Regression Test Result shows its significance score of $0.009 \leq 0.05$, it means that leadership influences the accounting information system quality. This research is in line with Jacob's (2012) which conclude that leadership ability of a group will influence the information system implementation. Key factors derived from this implementation have significant contribution in understanding the importance of leadership quality of all team members in achieving a goal. The same with Soja's (2009) research which concludes that information system will function well if the leadership process is accepted by the organization, therefore becoming the success key in information system implementation.

\subsection{Hypotheses Test Result of Organizational Structure Influence on Accounting Information System Quality (H2)}

Researcher will test hypotheses 2, which says "Organization structure influence on Accounting Information System Quality". Multiple Linear Regression Test Result shows a significance score of $0.034 \leq 0.05$, this means organization structure influences the accounting information system quality. This research is in line with Mukherji's (2002) research, in which he stated that information system and organization structure have strong connections with one another. The same with Bodnar and Hopwood (2014), they stated that organization structure influence the accounting information system because organization structure is a tool for the manager in governing policies, control, budget allocation and information service planning within an organization.

\subsection{Coefficient Determination Test Result}

After testing hypotheses using multiple linear regression test, and concluded that leadership and organization structure influence the accounting information system, therefore the researcher wants to know how much the two independent variables can explain the dependent variable using the coefficient of determination. Results of the coefficient determination shows the coefficient determination process result in the amount of $38.6 \%$. This means accounting information system quality variable can be explained by the leadership and the organization structure at $38.6 \%$ while the remaining $61.4 \%$ is explained by other factors. 


\section{Conclusion}

The purpose of this study was to determine the effect of leadership and organizational structure of the accounting information system quality. The results of the study received the first hypothesis which says leadership influence the accounting information system quality. Some research also state leadership affect the accounting information system has been undertaken by Bodie (2006) who said that leadership and integration of information technology management framework as a reputable approach that needs to be considered to achieve performance effectiveness of said organization. Huang and Hsu (2011) also explains that the charismatic leader has properties capable of affecting the employees in order to create a successful implementation of information systems. Furthermore, Goldkuhl and Rostlinger (2006) stated that only in the hands of a competent leader, information system can generate the information needed to determine rational decisions and enable precise control and coordination of every aspect within an organization. Furthermore, it is known that the second hypothesis which says oganization structure influence the accounting information system quality is also accepted. The same thing has been done by Mukherji (2002), in his empirical findings stated that information system and organization structure have a strong connection with one another. Internal organization structure is also affecting the success rate of information system projects. Indeje and Zheng (2010) explains that the organizational structure and the organizational culture affects the financial management information system. There has to be a harmony between a company's structure and infrastructure with an information system's structure and infrastructure (Modrak,2007). Leadership and organizational structure influence the accounting information system quality. To minimalize failure in the accounting information system quality, accounting information system development should involves the users, in this case, all organization members and all policies, standards and operational procedures have to always be documented in writing and be known to all organization members

\section{References}

Baltzan, P. (2012). Business Driven Information Systems ( $3^{\text {rd }}$ ed). New York: McGraw Hill.

Bass, B.M. \& Riggio, R.E. (2006). Transformational Leadership (2nd Ed.). USA: Lawrence Erlbaum Associates, Inc., Publishers.

Beest, V.F., Braam,G., \& Boelens,S. (2009). Quality of Financial Reporting: measuring qualitative characteristics. Netherland: Nijmegen Center for Economics NiCE Working Paper 09-108 April 2009 Institute for Management Research. Radboud University Nijmegen. HK Nijmegen,1-41.

Bodie, W.S. (2006). Transformational Leadership and Information Technology Management Integration Framework: A Normative Framework to Achieve Organizational Performance Effectiveness. IRMA International Conference, United States, 545-547.

Bodnar, G.H. \& Hopwood,W.S. (2014). Accounting Information Systems (10 ${ }^{\text {th }}$ Ed.). USA: Pearson Education, Inc

Cho, J., Park, I. \& Michel, J.W. (2011). How Does Leadership Affect Information Systems Success?The Role of Transformational Leadership. Information \& Management, 48(7), 270-277.

Goldkuhl, G. \& Rostlinger,A. (2006). Change Analysis-Innovation and Evaluation. Advances in Information Systems Development. 1., 17-25.

Greenberg, J. (2011). Behavior in Organizations (10th ed.). England: Pearson Education Limited

Guo,X., (2008). Failure of an Environmental Strategy: Lessons from an Explosion at Petrochina and Subsequent Water Pollution, in Schaltegger, S., Bennet,M., Buritt,R.L., Jasch,C., "Environmental management accounting for cleaner production", Springer Science + Business Media B.V.,Selected Reading pp.423-439.

Hall, J. A., (2011), Accounting Information Systems ( $7^{\text {th }}$ ed.), USA: South Western Cengage Learning

Huang, C.M., \& Hsu, P.Y. (2011). Perceptions of the impact of chief executive leadership style on organizational performance though succesful enterprise resource planning. Social Behavior and Personality, 39 (7), 865-878.

Indeje, W.G., \& Zheng,Q. (2010). Organizational Culture and Information Systems Implementation: A Structuration Theory Perspective. 2nd IEEE International Conference on Information and Financial Engineering, Shanghai,115.

Jacobs, A.J. (2012). Information System Implementations: Using a Leadership Quality Matrix for Success. USA: First Published by Author House.

Kavanagh, M.J.,Thite, M. \& Johnson, R.D. (2012). Human Resource Information Systems: Basics, Qualitys, and Future Directions (2nd Ed). USA: Sage Publications,Inc 
Laudon, K.C. and Laudon, J.P. (2007). Management Information Systems Managing The Digital Firm (10th Edition). USA: Pearson Education Inc. Pearson Prentice Hall

Lupasc, A., Lupasc, I., \& Zamfir, C.G. (2009). Methodologies for Developing the Agent-Oriented Systems in the Financial-Accoun ting Domain. The Annals of "Dunarea de Jos” University Galati fascicle I-2009. Economics and Applied Informatics. Years XV-ISSN 1584-0409, 581-588.

Mc Leod, R. \& Schell, G. (2001). Management Information Systems (Eight ed). New Jersey: Prentice Hall International,Inc.Upper Saddle River.

Mitchel, F., Smith,J., \& Reaid,J. (2000). Information system development in the small firm: the use of management accounting (1st Edition). London: CIMA Publishing.

Mukherji, A. (2002). The evolution of information systems: their impact on organizations and structure. Management Decision, 40 (5), 497-507.

Modrak, V. (2007). Bridging Organizational Structure and Information System Architecture Through Process. Advances in Web and Network Technologies and Information Management Lecture Notes in Computer Sciences. Vol 4537, 445-455.

Romney, M.B. \& Steinbart,P.J. (2012). Accounting Information Systems Global Edition (Twelfth Edition). USA: Pearson Education Limited

Sacer, Ivana M., Zager K., Tusek B. (2006). Accounting Information System's Quality as The Ground For Quality Business Reporting, IADIS International Conference e-commerce, ISBN :972 - 8924-23-2, 59-64.

Sciarra, D.J. \& Dorsey, A.G. (2012). Leaders and Supervisors in Child Care Programs. Canada: Thomson Learning

Soja, P. (2009). Enterprise System Implementation Issues: Learning from Field Study in Poland. Enterprise Information Systems, 3 (2), 1-28.

Stair, R.M. and Reynolds,G.W. 2010. Principles of Information Systems A Managerial Approach. Ninth Edition. USA: Course Technology, Cengage Learning.

Tricker, B. (1993). Hamessing Information Power. Hongkong: University Press

$\mathrm{Xu}, \mathrm{H}$. , (2009). Data quality issues for AIS' implementation: Systems, stakeholders, and organizational factors", Journal of Technology Research,1-11.

Wilkinson, J.W., Cerullo,M.J. \& Raval,V.(2000). Accounting Information Systems: Essential Concepts and Qualitys (Fourth Ed). USA: John Wiley \& Sons, Inc 